\title{
Jurist-Diction
}

Volume 4 No. 2, Maret 202

\section{Penataan Kewenangan Kelembagaan dan Pemberian Batasan Konstitusional sebagai Upaya Penataan Proses Legislasi Pasca Amandemen UUD NRI Tahun 1945}

\author{
Alif Duta Hardenta dan Tariq Hidayat Pangestu \\ Alifduta01@mail.ugm.ac.id \\ Universitas Gadjah Mada
}

How to cite:

Alif Duta Hardenta dan Tariq Hidayat Pangestu, 'Penataan Kewenangan Kelembagaan dan Pemberian Batasan Konstitusional sebagai Upaya Penataan Proses Legislasi Pasca Amandemen UUD NRI tahun 1945' (2021) Vol. 4 No. 2 Jurist-Diction.

\section{Histori artikel:}

Submit 4 Januari 2021;

Diterima 18 Februari 2021;

Diterbitkan 1 Maret 2021.

DOI:

10.20473/jd.v4i2.25748

p-ISSN: $2721-8392$

e-ISSN: $2655-8297$

\section{Abstract}

Reformasi changed the Indonesian constitution with amendments to Undang-Undang Dasar Tahun 1945 which emphasized the presidential system. However, the amendments do not reflect the presidential system that characterized with separation of powers, this can be seen in the imbalance of president's powers in legislation. It impacts the quality of laws produced by the legislatives, materially and formally. This study evaluates the weakness of DPD and vacuum of checks and balances in the legislative as well the problems with the President involvement. In addition, it also examines issues of legislation which not adhering to the good lawmaking principles, especially in formality. With juridicalnormative research method, the author evaluates the problems and propose solutions by reconstructing the institutions and strengthening the DPD.

Keywords: Laws; Dewan Perwakilan Daerah; Presidential System; Principle; Formal Reviews.

\section{Abstrak}

Reformasi memberikan perubahan bagi ketatanegaraan Indonesia dengan menghasilkan amandemen Undang-Undang Dasar Tahun 1945 yang menegaskan sistem presidensiil. Namun, pada kenyataannya hasil amandemen tidak mencerminkan sistem presidensiil yang bercirikan pemisahan kekuasaan, hal ini dapat dilihat dalam besarnya kewenangan presiden dalam legislasi. Hal ini berdampak pada buruknya produk undang-undang yang dihasilkan oleh kekuasaan legislatif, baik secara materiil maupun formil. Penelitian ini mengevaluasi pula lemahnya kewenangan DPD dalam legislasi dan kekosongan internal checks and balances dalam legislatif serta problematika pelibatan Presiden. Selain itu, ditinjau pula permasalahan legislasi yang dinilai tidak taat asas pembentukan peraturan perundang-undangan yang baik, khususnya secara formil. Dengan mengggunakan metode penelitian yuridis-normatif, penulis akan mengevaluasi problematika legislasi dan mengusulkan solusi dengan merekonstruksi lembaga yang terlibat dalam legislasi serta berkelindan dengan penguatan DPD.

Kata Kunci: Undang-Undang; Dewan Perwakilan Daerah; Presidensiil; Asas; Uji Formil. 


\section{Pendahuluan}

Reformasi membawa banyak perubahan fundamental dalam kehidupan berbangsa dan bernegara untuk menuju ke arah yang lebih demokratis. Salah satu langkah yang diambil adalah dengan melakukan perubahan UUD NRI tahun 1945 yang sudah dilakukan sebanyak 4 tahapan. Perubahan konstitusi tak ubahnya menjadi suatu yang lazim untuk dapat mengakomodir segala perubahan yang terjadi dalam penyelenggaraan negara. ${ }^{1}$ Selain itu menurut KC Wheare bahwa konstitusi pada prinsipnya adalah produk resultante berdasarkan situasi politik, sosial, dan ekonomi pada saat dibuat. ${ }^{2}$ Oleh sebab itu para perumus perubahan UUD NRI tahun 1945 menyadari bahwa perlu dibuat satu kesepakatan baru untuk mampu menyesuaikan dengan kondisi bangsa. Salah satu kesepakatan dalam melakukan perubahan UUD 1945 adalah untuk mempertegas sistem presidensiil dimana terdapat beberapa karakteristik yang salah satunya adalah adanya pemisahan kekuasaan antara kekuasaan eksekutif dan legislatif di berbagai aspek salah satunya adalah dalam proses legislasi. ${ }^{3}$ UUD 1945 sebelum perubahan memberikan kekuasaan lebih besar kepada eksekutif (executive heavy) tanpa batas kekuasaan yang jelas dan minus checks and balances antara lembaga-lembaga negara. ${ }^{4}$

Kontradiksi terjadi dimana semangat awal untuk menggeser fungsi legislasi menjadi kewenangan legislatf tidak terlalu signifikan. Marsilam Simanjuntak berpendapat amandemen yang dilakukan dengan tujuan menggeser sistem yang dahulunya berpusat pada lembaga eksekutif tidak terjadi karena perumus perubahan UUD 1945 tetap mempertahankan jiwa konstitusi lama. ${ }^{5}$ Akibatnya 4 tahapan perubahan gagal untuk menunjukkan adanya penguatan presidensiil dalam hal legislasi. Dapat dilihat dari ketentuan pasal 20 ayat (2) UUD NRI tahun 1945 yang menyatakan bahwa yang berimplikasi bahwa Presiden masih memiliki peran

\footnotetext{
${ }^{1}$ Karl Loewenstein, Reflections on the Value of Constitutions in Our Revolutionary Age (New York University Pers 1995).[203].

${ }^{2}$ KC Wheare, Modern Constitution (Oxford University Press 1975).[67].

3 Saldi Isra, Pergeseran Fungsi Legislasi (Raja Grafindo Persada 2018).[82].

4 ibid.[153].

5 Pan Mohammad Faiz, Amandemen Konstitusi : Komparasi Negara Kesatuan Dan Negara Federal (Raja Grafindo Persada 2019).[97].
} 
sentral dalam pembentukan undang-undang. Kondisi demikian kental dengan corak sistem pemerintahan parlementer yang memiliki corak adanya penggabungan antara cabang kekuasaan eksekutif dan cabang kekuasaan legislatif dalam hal legislasi yang menunjukkan pola saling ketergantungan. ${ }^{6}$

Besarnya kewenangan presiden seolah berbanding terbalik dengan peran Dewan Perwakilan Daerah (DPD) dalam proses legislasi. Secara historis cita awal dibentuknya DPD sebagai suatu perwakilan daerah ditujukan untuk merestrukturisasi bangunan parlemen Indonesia Indonesia menjadi dua kamar agar terjadi mekanisme internal checks and balances di Lembaga legislatif. ${ }^{7}$ Namun apabila melihat kewenangan DPD dalam hal legislasi sesuai pasal 22D UUD NRI 1945 yang hanya dapat mengajukan dan ikut membahas undang-undang tertentu saja menjadikan keberadaan DPD antara ada dan tiada. Menurut Stephan Sherlock DPD merupakan contoh tidak lazim dalam praktik Lembaga perwakilan dua kamar karena kewenangan yang dimilikinya amat terbatas namun disaat yang sama legitimasi yang ia dapat sangat tinggi. ${ }^{8}$ Dalam kedudukan yang seperti ini menurut Jimly Asshiddiqie pada akhirnya DPD hanya menjadi organ penunjang dari DPR semata. ${ }^{9}$ Implikasinya terkait artikulasi representasi kepentingan daerah menjadi sumir dalam pembentukan undang-undang.

Dalam tataran praktik terdapat problematika serius lainnya yang erat kaitannya dengan pembentukan undang-undang yaitu banyaknya pelanggaran-pelanggaran terhadap aspek formil yang sebenarnya telah diatur dalam Undang-Undang Nomor 12 tahun 2011 tentang Pembentukan Peraturan Perundang-Undangan (UU P3). Dalam hal ini permasalahan seperti keterbukaan hingga kedayagunaan pembentukan suatu undang-undang menjadi catatan merah. Contohnya dalam Undang-Undang Nomor 19 tahun 2019 tentang Perubahan Kedua Atas Undang-Undang Nomor 30 Tahun

\footnotetext{
${ }^{6}$ Juanz J Linz and Arturo Valenzuela, The Failure of Presidential Democracy (John Hopkins University Press 2001).[120].

7 Jimly Asshiddiqie, Format Kelembagaan Negara Dan Pergeseran Kekuasaan Dalam UUD 1945 (FH UII Press 2014).[17].

${ }^{8}$ DPD RI, DPD Bikameral Bukan Federal (Sekretariat DPD RI 2005).[76].

9 Jimly Asshiddiqie, Perkembangan Dan Konsolidasi Lembaga Negara Pasca Reformasi (FH UII Press 2012).[119].
} 
2002 Tentang Komisi Pemberantasan Tindak Pidana Korupsi, Undang-Undang Nomor 3 tahun 2020 tentang Perubahan atas Undang-Undang Nomor 4 tahun 2009 tentang Pertambangan Mineral dan Batubara, hingga Undang-Undang Cipta Kerja yang memiliki masalah serupa yaitu kurangnya keterbukaan hingga urgensi dibuatnya undang-undang a quo yang dinilai hanya untuk kepentingan kelompok tertentu. Praktik-praktik di atas sejatinya telah menabrak sejumlah asas formil dalam pembentukan undang-undang dan disaat yang bersamaan dapat membuat aspek materiil atau subtansi pengaturan juga menjadi problematik. Sehingga perlu dirumuskan suatu ketentuan yang dapat menjamin kepatuhan terhadap asas-asas pembentukan peraturan perundang-undangan ini serta merumuskan mekansime penegakan hukum yang efektif apabila tetap terjadi pelanggaran terhadap hal tersebut.

\section{Dewan Perwakilan Daerah dalam Model Kamar Parlemen di Indonesia}

Lembaga perwakilan merupakan institusi yang memiliki legitimasi paling kuat dalam pembentukan undang-undang yang mengikat warga negara yang ditujukan dalam rangka penyelenggaraan pemerintahan yang demokratis. Dalam Lembaga perwakilan terdapat beberapa variasi yang diklasifikasikan berdasarkan model kamar yang dibangun. Pemilihan sistem yang dipilih disesuaikan dengan dengan keadaan politik, social, ekonomi, etnik, serta faktor-faktor lainnya. ${ }^{10}$ Variasi lembaga perwakilan pertama adalah unicameral atau satu kamar yang tidak mengenal kamar kedua. Dalam hal ini rekrutmen untuk pengisian jabatan parlemen tidak membedakan representasi politik dan territorial atau pembedaaan lainnya. ${ }^{11}$ Berkaitan dengan permasalahan representasi model unicameral ini bisa menjadikan satu represnetasi berbasis partai politik, daerah, maupun golongan dalam satu kamar perwakilan. Terdapat beberapa keuntungan menggunakan model ini diantaranya dalam pembentukan Undang-Undang akan lebih cepat, pertanggungjawaban besar

${ }^{10}$ Dahlan Thaib, Menuju Parlemen Bikameral (Studi Konstitusional Perubahan Ketiga UUD 1945), Pidato Pengukuhan dalam jabatan Guru Besar Madya dalam Hukum Tata Negara Universitas Islam Indonesia (UII) Yogyakarta, tanggal 4 Mei 2002.[20].

11 Widayati, 'Sistem Parlemen Berdasarkan Konstitusi Indonesia' (2015) 44 Jurnal MMH. [417]. 
karena tidak ada alasan menyalahkan kamar lainnya, hingga secara biaya akan lebih rendah karena hanya terdiri atas satu kamar. ${ }^{12}$ Namun timbul kelemahan menyangkut lemahnya kontrol internal dalam parlemen yang mengakibatkan dalam menjalankan fungsinya seperti mengenai legislasi akan berkurang. ${ }^{13}$

Variasi lainnya dalam sistem parlemen adalah parlemen dengan dua kamar atau bicameral. Pembagian dua kamar ini ditujukan masing-masing kamar mewakili kepentingan entitas tertentu dan bukan merupakan suatu pola yang hierarkis. ${ }^{14}$ Dalam hal ini biasanya majelis tinggi adalah perwakilan kewilayahan hingga fungsional tertentu dan majelis rendah merupakan perwakilan rakyat berdasarkan proporsi politik penduduk. ${ }^{15}$ Berdasarkan hal tersebut diharapkan konstruksi yang timbul terkait aspirasi dari bebagai entitas di suatu negara mampu terakomodir dengan baik dalam lembaga legislatif. Urgensi diadakannya kamar kedua tak ubahnya untuk mencegah suatu pembentukan undang-undang maupun fungsi lainnya yang cenderung ceroboh. Kondisi ini terwujud karena dalam sistem bikameral masing-masing kamar memiliki kewenangan untuk mengawasi dan mengimbangi antara satu dengan yang lainnya. ${ }^{16}$ Selain itu jika diperhatikan penggunaan model bikameral diantaranya kegagalan model satu kamar untuk mengagregasikan seluruh kepentingan yang ada dimasyarakat yang sangat majemuk.

Terapat beberapa pembagian model kamar bikameral yaitu sistem bikameral yang kuat (strong bicameralism) dan sistem bikameral yang lemah (weak/soft bicameralism). Hal ini dapat ditinjau dari indikator seberapa kuat atau lemahnya kewenangan masing-masing kamar oleh konstitusi. ${ }^{17}$ Jika masing-masing kamar mempunyai kekuasaan yang sama maka cenderung yang timbul adalah sistem

${ }^{12}$ Mukti Fajar dan Yulianto Ahmad, Dualisme Peneltiaian Hukum Normatif Dan Empiris (1st edn, Pustaka Pelajar 2010).[9].

13 Saldi Isra and Zainal Arifin Mochtar, 'Konsep Ideal Bikameral Yang Sesuai Dengan Keadaan Dan Pemerintahan Demokratis Di Indonesia' (2007).[29].

${ }^{14}$ Widayati (n 20).[417].

15 Djatmiko Anom Husodo, Dewan Perwakilan Daerah Dan Masa Depan Bikameralisme Indonesia, Dalam Gagasan Amandemen UUD 1945 Suatu Rekomendasi (Komisi Hukum Nasional RI 2008).[250].

16 Sastro Wantu, 'Memperkuat Fungsi Legislasi DPRD Sebagai Format Policy Dalam Euphoria Otonomi Daerah’ (2012) 5 Jurnal Legalitas.[4].

17 Widayati (n 20).[418]. 
bikameral yang kuat begitupula jika kekuasaan yang diberikan antar kamar berbeda satu dengan yang lainnya maka cenderung timbul sistem bikameral yang lemah. ${ }^{18}$ Pola ini menurut Andrew Ellis membagi model bikameral menjadi yang lunak dan kuat melalui pendekatan pembuatan undang-undang dimana dalam sistem "kuat" biasanya dimulai dari majelis manapun kemudian dipertimbangkan oleh kedua majelis dalam forum yang sama sebelum bisa disahkan. ${ }^{19}$ Dalam sistem 'lunak', majelis yang satu memiliki status yang lebih tinggi dari yang lain, misalnya majelis pertama mungkin dapat menolak atau mengubah RUU yang diajukan oleh majelis kedua. ${ }^{20}$

Model kamar bikameral menjadi satu ketakutan tersendiri bagi Sebagian kelompok karena dikhawatirkan condong dengan bentuk negara federal. Namun, jika melihat perkembangan kekinian menurut penelitian Institute for Democracy and Electoral Assistans bahwa memang dalam negara federal semuanya menganut bikameral disaat yang bersamaan pula separuh negara kesatuan di seluruh dunia juga menggunakan sistem ini. Contohnya Belanda, Jepang, Perancis, Kamboja, hingga Filipina. ${ }^{21}$ Tidak relevan lagi jika terus menyangkutpautkan bikameralisme hanya dapat diterapkan dalam negara federal. ${ }^{22}$ Hipostesis ini dapat dibernarkan karena dalam negara kesatuan dengan wilayah yang luas dan tingkat kemajemukan tinggi opsi kamar kedua untuk mampu lebih merepresentasikan kepentingan masyarakat tersebut menjadi suatu hal yang diperlukan. Selain itu negara-negara kesatuan kemudian menerapkan sistem bikameralisme dengan alasan check and balances serta keinginan untuk membentuk sistem pemerintahan yang lebih efisien dan efektif dengan adanya revising chamber dalam pengambilan keputusan kebijakan, atau yang dikenal dengan sistem double check. ${ }^{23}$ Oleh sebab itu, kekhawatiran berlebihan yang berkaitan dengan bentuk negara telah dapat dipatahkan dengan fakta yang ada.

\footnotetext{
18 ibid.

19 Michael Hishikusthija, Perbandingan Bikameral Dan Proses Perubahan Konstitusional (Forum Rektor Indonesia 2001).[44].

${ }^{20}$ ibid.

${ }^{21}$ Widayati (n 20).[418].

${ }^{22}$ Djatmiko Anom Husodo (n 24).[250].

${ }_{23}$ Jimly Asshiddiqie, Perkembangan Dan Konsolidasi Lembaga Negara Pasca Reformasi (Sinar Grafika 2012).[7-8].
} 
Dalam konteks lembaga perwakilan di Indonesia, eksistensi DPD merupakan salah satu buah reformasi untuk menjamin kepentingan daerah mampu tersalurkan dengan baik. Mengingat secara teoritik DPD memegang peran sebagai regional representatives berbeda dengan DPR yang merupakan national/political representatives. ${ }^{24}$ Secara historis pembentukan DPD ditujukan untuk merombak struktur parlemen Indonesia menjadi bikameral yang tujuannya agar terjadi internal checks and balances yang efektif dalam Lembaga perwakilan. ${ }^{25}$ Eksistensi DPD sebagai kamar tersendiri dalam Lembaga legislatif memberikan sejumlah keuntungan dari segi representasi masyarakat, khususnya mengenai kemampuan anggota. Pertama, seorang anggota DPD dapat mewakili pemilih dengan latar belakang yang beragam, misalnya, wilayah, etnik, atau golongan; Kedua, anggota DPD dapat mencegah pengesahan Undang-Undang yang cacat atau ceroboh; Ketiga, Pengawasan atau pengendalian oleh DPD yang lebih baik atas lembaga eksekutif. ${ }^{26}$ Akan tetapi pada tataran praktik keberadaan DPD antara ada dan tiada.

\section{Problematika Kontradiktif Kewenangan Presiden dan DPD dalam Proses Legislasi}

Keberadaan dan keterlibatan Presiden selaku representasi dari kekuasaan eksekutif merupakan fokus utama dalam setiap amandemen terhadap konstitusi. Kekuasaan eksekutif dalam sistem presidensiil menempatkan Presiden dalam kedudukan ganda yaitu sebagai kepala pemerintahan dan kepala negara. ${ }^{27}$ Meski terdapat kedudukan ganda tersebut, diskursus dalam sistem presidensiil adalah mengenai bagaimana pemisahan kekuasaan (separation of power) antara kekuasaan legislatif dengan kekuasaan eksekutif itu sendiri untuk menghindarkan penumpukan

${ }^{24}$ Jimly Asshiddiqie, Format Kelembagaan Negara Dan Pergeseran Kekuasaan Dalam UUD 1945 (FH UII Press 2004).[49].

25 Jimly Asshiddiqie, Format Kelembagaan Negara Dan Pergeseran Kekuasaan Dalam UUD 1945 (n 7).[17].

${ }^{26}$ Dhalan Thaib, 'Menuju Parlemen Bikameral', SIdang Senat Terbuka UII Yogyakarta (FH UII Press 2003).[87-88].

27 Arend Lijphart, Patterns of Democracy: Government Forms and Performance in Thirty-Six Countries (Yale University 1999).[20]. 
pada satu organ semata. ${ }^{28}$ Pemahaman pemisahan kekuasaan ini dilandasi oleh keyakinan bahwasanya hanya kekuasaan legislatif yang memegang urusan pembentukan Undang-Undang, sedangkan di satu sisi kekuasaan eksekutif hanya fokus dalam menjalankan administrasi dan aturan dari Undang-Undang tersebut. Akan tetapi upaya untuk mempertegas sistem presidensiil dalam melakukan perubahan UUD NRI tahun 1945 menemui titik kegagalan. Hal ini terlihat dengan kewenangan Presiden selaku representasi eksekutif justru diberikan kekuasaan untuk membentuk Undang-Undang yang seharusnya merupakan kewenangan bagi legislatif. ${ }^{29}$ Lebih lanjut menurut Bagir Manan perubahan UUD NRI tahun 1945 tidak terjadi pemisahan kekuasaan antara DPR dan Presiden dalam pembentukan undang-undang ${ }^{30}$ Padahal sistem yang melibatkan eksekutif dalam legislasi memberikan implikasi pelemahan terhadap masing-masing kekuasaan tersebut, dimana kekuasaan eksekutif akan bergantung kepada kekuasaan legislatif dan begitu pula sebaliknya.

Ketergantungan antar kekuasaan tersebut dapat menimbulkan kebuntuan politik berupa deadlock dalam proses legislasi. Hal ini dapat terjadi ketika legislatif tidak menyetujui RUU dari pemerintah, begitupula sebaliknya, membuat suatu RUU tersebut tidak akan menjadi Undang-Undang. ${ }^{31}$ Padahal disaat yang bersamaan pula bisa jadi suatu undang-undang tersebut merupakan kebutuhan hukum masyarakat. Hal ini juga bisa membuat adanya ketegangan hubungan antara legislatif dan pemerintah yang berkepanjangan. Problematika penolakan tersebut menjadi semakin rumit di Indonesia karena adanya perpaduan dengan sistem pemilihan umum dengan partai majemuk (multipartai) yang menyulitkan dalam mencapai kesepakatan bersama. Hal ini terjadi ketika Presiden yang terpilih, berasal dari partai politik minoritas yang ada dalam parlemen yang dapat mengakibatkan pemerintahan yang terbelah (divided government). ${ }^{32}$ Dalam hal ini pekerjaan

\footnotetext{
${ }^{28}$ Budiardjo (n 16).[21].

${ }^{29}$ Giovanni Sartori, Comparative Constitutional Engineering (Palgrave Macmillan 1998).[84].

30 Bagir Manan, DPR, DPD, Dan MPR Dalam UUD 1945 Baru (FH UII Press 2003).[22].

${ }^{31}$ Saldi Isra, Pergeseran Fungsi, Op.Cit.[6].

32 Denny Indrayana, Teori Lembaga Kepresidenan (Departemen HTN FH UGM [s.a]). [115].
} 
eksekutif berpotensi dihadang dan tidak dapat terlaksana, namun disisi lain apabila Presiden terpilih berasal dari partai politik mayoritas yang ada dalam parlemen, maka akan menciptakan problematika baru. ${ }^{33}$ Dalam kondisi ini disebut sebagai majoritarian government/unified government, yang kemudian mengakibatkan tidak berjalan dengan efektifnya sistem check and balances antara kekuasaan eksekutif dan legislatif. ${ }^{34}$ Keberadaan yang sama disertai dengan kepentingan yang sama dimana sama-sama diajukan oleh partai politik memungkinkan adanya 'kongkalikong' terhadap pembentukan undang-undang. Konkritnya menurut Zainal A. Mochtar, adalah besarnya barter undang-undang antara DPR dan Presiden. ${ }^{35}$

Aturan dimana kekuasaan eksekutif dilibatkan dalam pembentukan UndangUndang sebenarnya hanya dikenal dalam sistem pemerintahan parlementer. Hal ini dikarenakan sistem parlementer tidak mengenali separation of power, sehingga terjadi percampuran kekuasaan antara eksekutif dan legislatif dalam setiap tahap pembentukan Undang-Undang. ${ }^{36}$ Kekuasaan dalam sistem parlementer memiliki keunikan dimana seorang Perdana Menteri yang merupakan kepala pemerintahan dan representasi eksekutif disaat yang sama merangkap jabatan sebagai anggota legislatif yang memegang kekuasaan pembentukan Undang-Undang. ${ }^{37}$ Perubahan Ketiga UUD 1945 mengamanatkan DPD agar menjadi penyeimbang kewenangan legislasi yang dimiliki oleh DPR. Hal ini dikarenakan DPR yang berasal dari partai politik, masih merepresentasikan kepentingan kebijakan partai politik pada tingkat pusat atau masih adanya unsur sentralistik dalam kepartaian tersebut. ${ }^{38}$ Oleh karena itu, wakil daerah dalam DPD terdiri atas tokoh-tokoh yang dapat mewakili seluruh elemen masyarakat daerah dalam memahami permasalahan daerah yang

\footnotetext{
${ }^{33}$ ibid. [114].

${ }^{34}$ ibid.

${ }^{35}$ Icha Rastika, 'Sistem Pembuatan UU Di Indonesia Buka Peluang Barter Antara Pemerintah-DPR' (Kompas.com, 2015) < https://nasional.kompas.com/read/2015/09/30/05170021/Sistem. Pembuatan.UU.di.Indonesia.Buka.Peluang.Barter.antara.Pemerintah-DPR?page $=$ all $>$ accessed 23 October 2020.

${ }^{36}$ Saldi Isra, Pergeseran Fungsi, Op.Cit.[5].

37 ibid.

${ }^{38}$ Satjipto Rahardjo, Sisi-Sis Lain Dari Hukum Di Indonesia (Penerbit Kompas 2003).[3].
} 
diwakilinya. ${ }^{39}$ Pembedaan filosofis perwakilan ini penting untuk menghindari double representation atau keterwakilan ganda oleh kedua lembaga legislatif tersebut dalam proses legislasi. ${ }^{40}$ Keberadaan dua lembaga legislatif diharapkan pula dapat menghindari "monopoli" dalam pembentukan undang-undang, yang dikhawatirkan menciptakan Undang-Undang yang terkesan semena-mena, atau ceroboh. ${ }^{41}$ Lemahnya kedudukan dan kewenangan DPD sebenarnya merefleksikan sikap setengah hati dalam mereformasi dan merestrukturisasi Lembaga perwakilan. ${ }^{42} \mathrm{Hal}$ ini dapat dilihat dari konstruksi yang dibangun dalam ketentuan 20 ayat (1) UUD NRI tahun 1945 yang secara terang menyatakan bahwa DPR memegang kekuasaan membentuk undang-undang. DPD yang hakikatnya dijadikan sebagai kamar kedua dalam lembaga perwakilan langsung mendapatkan pukulan telak dengan adanya ketentuan a quo.

Lemahnya kewenangan DPD selanjutnya dapat dilihat dalam ketentuan pasal 22D ayat (1) UUD NRI tahun 1945 yang menyatakan bahwa DPD 'dapat' mengajukan RUU tertentu. Terkait pasal ini menurut Bivitri Susanti menjadikan DPD tidak memiliki suatu signifikansi sebagai suatu institusi yang mengajukan RUU. ${ }^{43}$ Berbeda misalnya dengan ketentuan pasal 5 ayat (1) maupun pasal 21 UUD NRI tahun 1945 yang menyatakan Presiden dan anggota DPR berhak mengajukan rancangan-undang. Selain itu subordinasi ini juga dihasilkan oleh ketentuan pasal 22D ayat (2) UUD NRI tahun 1945 yang hanya memberikan DPD untuk "ikut membahas" dan "memberikan pertimbangan" menyiratkan hadirnya DPD sangatlah sumir dalam menentukan disetujui atau tidaknya suatu RUU. Frasa "ikut membahas" menurut Jimly Asshiddiqie sebenarnya secara implisit menyatakan DPD hanya sebagai pelengkap wewenang DPR dan Presiden. ${ }^{44}$ Hal ini dikarenakan

\footnotetext{
${ }^{39}$ ibid.

${ }^{40}$ Jimly Asshiddiqie, Konstitusi Dan Konstitusionalisme Di Indonesia (Sinar Grafika 2011).[152].

${ }^{41}$ Dahlan Thaib Op.Cit.[9].

${ }^{42}$ Sri Soemantri, Mengawal Konstitusi (Unpad Press 2006).[285-287].

${ }^{43}$ Bivitri Susanti, 'Penguatan Kewenangan DPD Dan Pasal-Pasal Lain Yang Terkait Di Bidang Legislasi, Anggaran, Dan Pengawasan', Pertemuan Ahli Hukum Tata Negara, Universitas 1945 Makassar (Universitas 1945 Makassar 2007).[20].

44 Saldi Isra, Op.Cit.,2018.[301].
} 
dalam pasal 20 ayat (2) UUD NRI tahun 1945 dinyatakan bahwa suatu RUU dibahas oleh DPR dan Presiden untuk mendapatkan persetujuan Bersama.

Perdebatan mengenai lemahnya kewenangan DPD dalam memperjuangkan aspirasi dibuktikan dengan sedikitnya jumlah RUU (RUU) yang murni merupakan usulan DPD. ${ }^{45}$ Sejumlah usulan RUU yang diajukan oleh DPD, yaitu seperti RUU tentang Wawasan Nusantara (diajukan tahun 2015), RUU tentang Ekonomi Kreatif (diajukan tahun 2016), RUU tentang Penyelenggaraan Pemerintah di Wilayah Kepulauan (diajukan tahun 2017), RUU tentang Bahasa dan Kesenian Daerah (diajukan tahun 2020), dan RUU tentang Daerah Kepulauan (diajukan tahun 2020). ${ }^{46}$ Hal ini mencerminkan bahwasanya DPD kurang efektif dalam penyampaian aspirasi masyarakat daerah di parlemen. Selain itu, problematika kewenangan legislasi berimplikasi pada lamanya proses legislasi. Contoh nyata dari panjangnya pembahasan tersebut dapat dilihat dalam RUU tentang Daerah Kepulauan. RUU tersebut merupakan produk UU yang dianggap mendesak oleh DPD untuk mengurangi kesenjangan antardaerah. Adapun dalam proses legislasi terjadi permasalahan dimana RUU a quo sudah dibahas di periode 2014-2019, namun belum berhasil disahkan menjadi UU. ${ }^{47}$ Akibatnya, RUU a quo tidak termasuk carry over dari periode lalu sehingga harus dibahas dari awal, namun diharapkan segera selesai karena pembahasannya sudah selesai di DPD RI. ${ }^{48}$

\section{Praktik Pembentukan Undang-Undang yang Tidak Demokratis}

Perubahan undang-undang adalah yang harus ada agar dapat mengikuti perkembangan kehidupan masyarakat. Hal ini menurut Sudikno Mertokusumo suatu undang-undang selalu berjalan di belakang peristiwa (het recht hinkt achter

${ }^{45}$ Ditjen Peraturan Perundang-Undangan, 'Prolegnas 2015-2019',(Ditjen PP Kemenkumham, $2015)<$ http://ditjenpp.kemenkumham.go.id/prolegnas-2015-2019.html> accessed 15 October 2020.

${ }^{46}$ DPR RI, 'Program Legislasi Nasional Prioritas RI - Prolegnas 2015-2019 dan Prolegnas 2020-2024’ (DPR RI 2020), < http://www.dpr.go.id/uu/prolegnas> accessed 27 October 2020.

${ }^{47}$ Liputan6.com, 'DPD Targetkan RUU Daerah Kepulauan Disahkan pada 2020' (Liputan 6.com 2019) <https://www.liputan6.com/news/read/4140154/dpd-targetkan-ruu-daerah-kepulauandisahkan-pada-2020> accessed 1 November 2020.

48 ibid. 
de feiten aan). ${ }^{49}$ Dalam negara hukum menurut Maria Farida pembentukan undangundang adalah menciptakan modifikasi atau perubahan kehidupan masyarakat. ${ }^{50}$ Idealnya suatu undang-undang merupakan manifestasi dari kebutuhan masyarakat dalam kehidupan bernegara. Hal ini sejalan dengan yang dirumuskan ketentuan pasal 10 ayat (1) UU P3 yang menyebutkan bahwa salah satu materi muatan undangundang adalah pemenuhan kebutuhan hukum dalam masyarakat. Tak ubahnya pembentuk undang-undang, dalam hal ini DPR dan Presiden serta DPD yang sumir merupakan representasi dari masyarakat untuk menyampaikan aspirasinya termasuk dalam ketentuan undang-undang. Konstruksi ini timbul karena ketiga lembaga tersebut dipilih melalui pemilu sebagai sarana perwujudan kedaulatan rakyat yang berimplikasi agar nantinya orang-orang yang terpilih timbul kesadaran politis bahwa mereka dengan rakyat tidak seharusnya berjarak. ${ }^{51}$ Oleh sebab itu sudah seharusnya dalam pembentukan suatu undang-undang haruslah melibatkan masyarakat di dalamnya.

Sebagai jaminan agar suatu undang-undang berkualitas dan sesuai dengan kebutuhan hukum dalam masyarakat haruslah sesuai asas-asas pembentukan peraturan perundang-undangan. Hal ini ditujukan agar suatu pembentukan peraturan perundang-undangan tidak memihak atau menguntungkan kelompok tertentu serta mengindari adanya undang-undang yang mengancaman kebebasan warga negara serta untuk menjamin efektif berlakunya suatu undang-undang. ${ }^{52}$ Asas pembentukan peraturan perundang-undangan menurut Maria Farida adalah suatu rambu-rambu dalam pembentukan peraturan perundang-undangan yang baik..$^{53}$ Dalam hal ini asas pembentukan peraturan perundang-undangan mencakup asas formal maupun asas materill. Asas formal menurut Hamid Attamimi tercakup asas tujuan yang jelas,

\footnotetext{
${ }^{49}$ Soedikno Mertokusumo, Mengenal Hukum: Suatu Pengantar (Penerbit Liberty 2003).[103].

${ }^{50}$ Sally Falk Moore, 'Law and Social Change: The Semi-Autonomous Social Field As An Approriate Subject of Study' (1973) 7 Law and Society Review.[721].

${ }^{51}$ Saldi Isra, Pemilu Dan Pemulihan Daulat Rakyat (Themis Publishing 2017).[106].

${ }^{52}$ Bayu Dwi Anggono, Perkembangan Pembentukan Undang-Undang Di Indonesia (Konstitusi Press 2014).[46-47].

${ }^{53}$ Maria Farida Indrati, Ilmu Perundang-Undangan 1: Jenis, Fungsi, Dan Materi Muatan (Kanisius 2002).[5-6]
} 
perlunya pengaturan, organ pembentuk yang tepat, materi muatan yang tepat, dapat dilaksanakan, dan dapat dikenali. ${ }^{54}$ Sedangkan asas materiil tercakup bahwa sesuai dengan cita hukum Indonesia, norma fundamental negara, hykum dasar negara, prinsip negara hukum, dan supremasi konstitusi. ${ }^{55}$ Asas pembentukan peraturan perundang-undangan ini diformalkan dalam ketentuan pasal 5 UU P3 meliputi asas kejelasan tujuan, kelembagaan yang tepat, kesesuaian antara jenis, hierarki, dan materi muatan, dapat dilaksanakan, kedayagunaan dan kehasilgunaan, kejelasan rumusan, dan keterbukaan, Perlu digarisbawahi mengenai asas keterbukaan, dalam penjelasan pasal a quo disebutkan bahwa dalam pembetukan peraturan perundangundangan mulai dari perencanaan, penyusunan, pembahasan, pengesahan, dan pengundangan bersifat transparan dan terbuka. Konsekuensi yuridisnya adalah seluruh lapisan masyarakat mempunyai kesempatan seluas-luasanya untuk memberikan masukan dalam pembentukan peraturan perundang-undangan. ${ }^{56} \mathrm{Hal}$ ini menjadi penting karena menurut Sally Falk Moore yang mengutip Weber yang menyatakan bahwa pihak terkait yang secara langsung berpartisipasi dalam suatu aspek kehidupan lebih memahami kondisi aspek kehidupan tersebut dibandingkan pihak lain yang hanya menggunakan kacamata teori. ${ }^{57}$

Untuk mewujudkan suatu undang-undang yang sesuai baik dan sesuai dengan kebutuhan hukum masyarakat haruslah memiliki landasan yang kokoh mengapa suatu undang-undang dibentuk. Landasan ini mencakup landasan filosofis, yuridis, sosiologis yang dapat ditemukan dalam naskah akademik.. Pembentukan suatu undang-undang harus disertai oleh naskah akademik berdasarkan ketentuan pasal 43 UU P3. Lebih lanjut naskah akademik berisi latar belakang, tujuan penyusunan, sasaran, ,pokok pikiran, lingkup dan objek yang diaturm serta arah dan jangkauan

\footnotetext{
${ }^{54}$ Hamid S Attamimi, Peranan Keputusan Presiden Republik Indonesia Dalam Penyelenggaraan Pemerintahan Negara: Suatu Studi Analisis Mengenai Keputusan Presiden Yang Berfungsi Pengaturan Dalam Kurun Waktu Pelita I-Pelita IV (Pascasarjana FH UI 1990).[344-345]. ${ }^{55}$ ibid.

${ }^{56}$ Putera Astomo, Ilmu Ilmu Perundang-Undangan : Teori Dan Paktik Di Indonesia (Raja Grafindo Persada 2018).[98].

${ }^{57}$ Sally F. Moore, Law And Social Change, Op.Cit.[721].
} 
pengaturan. ${ }^{58}$ Naskah akademik ini adalah langkah paling fundamental yang menurut Jimly Asshiddiqie semata-mata agar suatu undang-undang benar-benar disusun berdasarkan pemikiran yang matang dan mendalam semata-mata agar tercapainya kepentingan umum..$^{59}$

Kontradikasi terjadi dalam praktik yang menyimpangi kewajiban yuridis yang telah digariskan oleh UU P3. Pada kasus ini banyak ditemukan pembentuk undangundang seolah membangkang asas-asas pembentukan peraturan perundang-undang terkhusus asas keterbukaan hingga praktik naskah akademik 'susulan'. Contohnya adalah terkait diundangkannnya Undang-Undang Nomor 3 tahun 2020. UU $a$ quo menimbulkan berbagai tanggapan miring dari masyarakat sipil dimana kuat kemungkinan tidak adanya naskah akademik yang mendasari perubahan tersebut. Salah satunya disuarakan oleh ahli hukum agraria, Maria SW Sumardjono yang menyatakan keraguannya terhadap perubahan UU Minerba tersebut karena tidak sesuai dengan kebutuhan dan kemungkinan tidak adanya naskah akademik ketika UU a quo diinisiasi. ${ }^{60}$

Begitu pula dalam Undang-Undang No. 19 tahun 2019 yang juga dipertanyakan mengenai keterbukaan dan transparansi pembentukannya. Perubahan undangundang yang mendapat kecaman dengan serentaknya aksi masa di banyak wilayah di Indonesia ini mendapat banyak pandangan miring dari berbagai pihak. Lebih lanjut menurut Richo Andi Wibowo revisi yang sangatlah cepat tak ubahnya suatu bentuk 'simsalabim' yang bertambah buruk karena sulitnya akses terhadap naskah akademik dan pembentukan yang serba tertutup sehingga akses masyarakat untuk memberikan masukan dan kritik juga seolah ditutup. ${ }^{61}$ Selain itu, contoh terbaru

\footnotetext{
${ }^{58}$ Vide Pasal 33 ayat (2) Undang-Undang Nomor 12 Tahun 2011 tentang Pembentukan Peraturan Perundang-undangan.

${ }^{59}$ Jimly Asshiddiqie, Perihal Undang-Undang Di Indonesia (Sekretariat Mahkamah Konstitusi RI 2006).[320].

${ }^{60}$ Chandra Iswinarno, 'Tak Ada Kajian Naskah Akademik, Guru Besar UGM Ragukan UU Minerba Yang Baru' (Suara.com, 2020). <. https://www.suara.com/news/2020/05/13/145404/ tak-ada-kajian-naskah-akademik-guru-besar-ugm-ragukan-uu-minerba-yang-baru> accessed 19 October 2020.

${ }^{61}$ Richo Andi Wibowo, 'Masalah Turunan Pasca "Sulap” UU KPK' (JawaPos, 2019). < https://www.jawapos.com/opini/18/09/2019/masalah-turunan-pasca-sulap-uu-kpk/> accessed 19 October 2020
} 
dalam pengundangan Undang-Undang Cipta Kerja yang mendapat pandangan miring terkait proses pembentukannya. Hal ini disampaikan oleh Zainal Arifin Mochtar dimana dengan sulitnya masyarakat mengakses draft final UU Cipta Kerja adalah preseden buruk pembentukan undang-undang dalam hal transparansi. ${ }^{62}$ Atas beberapa contoh pembentukan undang-undang di atas memiliki satu persamaan yaitu adanya kecacatan secara formil atau procedural dimana batasan-batasan yang ada secara sadar di terabas oleh pembentuk undang-undang. Idealnya hal tersebut dapat diuji formilkan terhadap Undang-Undang Dasar NRI tahun 1945 kepada Mahkamah Konstitusi sebagaimana salah satu kewenangan yang diberikan pasal 24C ayat (1) UUD NRI tahun 1945 untuk menguji undang-undang terhadap UUD NRI tahun 1945. Namun jika dibaca secara utuh ketentuan dalam Undang-Undang Dasar NRI tahun 1945 tidak secara rigid mengatur mengenai aspek prosedural ini sehingga terdapat ketidakjelasan mengenai dasar batu uji yang akan digunakan.

\section{Rekonstruksi Kelembagaan dan Kewenangan Pembentuk Undang-Undang}

Sebagai salah satu upaya dalam memurnikan sistem presidensiil, proses legislasi pada status quo yang memberikan kewenangan yang besar pada Presiden harus digeser sehingga pembentukan undang-undang menjadi domain kekuasaan legislatif. Konstruksi ini berimplikasi pada penguatan DPD dalam penataan pola legislasi. Hal ini bertujuan untuk mewujudkan produk Undang-Undang yang lebih mengakomodir aspirasi masyarakat dan merepresentasikan masyarakat daerah. Penguatan DPD dapat menyelesaikan permasalahan legislasi yang pada praktik $a$ quo dimonopoli oleh DPR yang dapat memberikan celah bagi produk UndangUndang yang tidak demokratis dan mencerminkan kedaulatan rakyat. Adapun gagasan rekonstruksi pembentukan undang-undang yang pertama adalah dengan mengubah ketentuan pasal 20 ayat (1) UUD NRI tahun 1945 menjadi "Dewan

62 BBC News Indonesia, 'Isi Omnibus Law: Dokumen Final UU Cipta Kerja Belum Diakses Publik, Dikhawatirkan Pasal Selundupan’ (BBC Indonesia, 2020) <https://www.bbc.com/ indonesia/indonesia-54501112> accessed 11 October 2020. < https:/www.bbc.com/indonesia/ indonesia-54501112> accessed 19 October 2020. 
Perwakilan Rakyat dan Dewan Perwakilan Daerah memegang kekuasaan lembaga legislaif'. Tujuannya adalah sebagai jaminan bahwa DPR dan DPD memiliki kewenangan yang setara baik dalam hal legislasi, anggaran, maupun pengawasan. Hal ini menjadi logis karena dalam lembaga legislatif antara fungsi legislasi, fungsi anggaran maupun fungsi pengawasan akan sangat berkaitan satu dengan lainnya. ${ }^{63}$

Pada tahapan pengajuan RUU dapat dilakukan oleh anggota DPR, anggota DPD, atau Presiden. Rasio memberikan kewenangan pengajuan RUU kepada anggta DPR dan anggota DPD tak ubahnya karena hal ini merupakan kewenangan yang melekat pada kekuasaan lembaga legislatif. Dalam hal ini tidak ada pembedaan undang-undang yang dapat diajukan oleh anggota DPR dan DPD. Sedangkan dalam mekansime ini Presiden tetap dapat mengajukan suatu RUU dikarenakan dalam sistem presidensiil kapasitasnya sebagai kepala negara dan kepala pemerintahan. ${ }^{64}$ Selain itu Bagir Manan menyatakan bahwa dalam hal inisiasi RUU Presiden memiliki dominasi yang dianaranya disebabkan ia secaa detail memahami permasalahan konkrit terkait kebutuhan untuk menjalankan kebijaksanaan dan penyelenggaraan pemerintahan serta Presiden lebih mempunyai kesemapatan untuk mendapatkan tenaga ahli di bidang-bidang tertentu. ${ }^{65}$ Selain itu pula apabila melihat tata kerja eksekutif memungkinkan keputusan diambil lebih cepat dibandingkan dengan lembaga legislatif yang bersifat kolegial. ${ }^{66}$ Dalam hal ini Presiden diharapkan dalam mengajukan RUU mampu berisi disintesis dari permasalahan dan kebutuhan hukum masyarakat.

Kemudian tahapan selanjutnya terkait pembahasan dan persetujuan akan murni menjadi domain kewenangan DPR dan DPD sebagai lembaga pemegang kekuasaan legislative. Hal ini menjadi satu urgensi tersendiri jika dikaitkan dengan pembentukan undang-undang dalam sistem presidensiil titik acuan yang penting adalah memastikan bahwa dalam tahapan pembahasan dan persetujuan merupakan

\footnotetext{
${ }^{63}$ Bagir Manan, DPR,DPD, dan MPR, Op. Cit.[37-38].

${ }^{64}$ Arend Lijphart, Op.Cit.[43-48].

${ }^{65}$ Bagir Manan, Lembaga Kepresidenan (Gama Media 1999).[134].

${ }^{66}$ ibid.
} 
kewenangan lembaga legislative dan tidak ada model mutual dengan eksekutif. ${ }^{67}$ Mendasarkan hal ini mekanisme baru yang diusulkan Penulis jika suatu RUU yang diajukan anggota DPR dan Presiden akan diserahkan kepada pimpinan DPR untuk dilakukan pembahasan pertama di DPR untuk mendapatkan persetujuan. Sedangkan dalam hal suatu RUU diajukan oleh DPD diajukan kepada pimpinan DPD untuk dilakukan pembahasan pertama di DPD untuk mendapatkan persetujuan. Setelah mendapatkan persetujuan di masing-masing kamar akan 'dioper' ke kamar lainnya untuk mendapatkan persetujuan kedua. Dalam hal ini jika tidak mendapatkan persetujuan kedua dari masing-masing kamar maka RUU tersebut batal untuk menjadi undang-undang dan tidak dapat diajukan lagi dalam persidangan masa itu. Namun, menurut Penulis perlu memberikan opsi masing-masing kamar untuk membentuk komisi bersama yang berisi perwakilan yang jumlahnya proporsional antara DPR dan DPD untuk melakukan penyelarasan aspirasi kedua lembaga sehingga terdapat kesepakatan atau consensus untuk mencapai persetujuan kedua. Dengan demikian dapat disimpulkan masing-masing kamar telah memberikan persetujuannya yang juga menjadi bukti adanya internal checks and balances yang optimal masing-masing kamar.

Setelah mendapatkan persetujuan kedua ini kemudian barulah Presiden dapat terlibat dalam hal pengesahan. Hal ini didasarkan secara komparatif di beberapa negara dengan sistem presidensiil seperti Venezuela, Amerika Serikat, Korea Selatan, Filipina, dan Argentina bahwa keterlibatan Presiden baru muncul setelah suatu RUU dibahas dan disetujui lembaga legislatif. ${ }^{68}$ Sebagai pelaksana dari Undang-Undang, Presiden diberikan hak veto terhadap RUU yang telah disetujui oleh DPR dan DPD. Tujuan adanya mekanisme sebagai suatu langkah untuk melindungi presiden dari penyelewenangan yang mungkin dilakukan lembaga legislative dengan menyetujui undang-undang ang tidak layak. ${ }^{69}$ Selain itu pula mekanisme ini menjamin adanya

\footnotetext{
${ }^{67}$ Saldi Isra, Pergeseran Fungsi, Op.Cit.[352].

${ }^{68}$ ibid.

${ }^{69}$ John H Garvey and Alexander Aleinikoff, Modern Constitutional Theory: A Reader 5th Edition (West Group Publishing 1999).[292].
} 
checks and balances antara Presiden dengan lembaga legislative yang efektif. Oleh sebab itu, nantinya veto yang dilakukan oleh Presiden dapat dilakukan pembatalan veto (override veto) oleh DPR dan DPD dimana masing-masing kamar harus mencapai jumlah persetujuan tertentu sehingga undang-undang tetap sah dan harus diundangkan. Jika kuorum persetujuan pembatalan veto oleh masing-masing kamar tidak tercapai maka undang-undang batal berlaku. Hasil dari rekonstruksi kelembagaan yang terlibat dalam proses legislasi ini akan menjamin efektifitas terkait mekanisme checks and balances baik internal lembaga legislative maupun antara ekfekutif dan legislative yang sesuai dengan sistem presidensiil. Selain itu, dengan terlibatnya DPD secara penuh dalam proses legislasi dimana kewenangannya setara dengan DPR akan menjamin perannya untuk dapat membawa atau aspirasi daerah yang selama ini masih terpinggirkan.

\section{Pemberian Batas Konstitusional Pembentukan Undang-Undang}

Permasalahan cacat formil atau procedural dalam pembentukan undangundang jangan sampai dijadikan suatu kebiasaan atau preseden yang terus menerus berulang. Hal ini dikarenakan berbicara mengenai aspek procedural akan sangat berkait dengan subtansi suatu ketentuan undang-undang. Kaitan ini menurut Susi Dwi Harijanti dalam due process of law, terdapat due process of substantive dan due process of procedural dalam hal ini tanpa memenuhi hak-hak procedural seperti keterlibatan masyarakat dan prinsip keterbukaan lainnya maka hak-hak subtantif tidak dapat dipenuhi. ${ }^{70}$ Pembangkangan terhadap aspek prosedural sebagaimana diatur dalam UU P3 membawa urgensi bahwa aspek formil pembentukan suatu undang-undang perlu diatur lebih tegas dalam konstitusi. Tujuan utamanya tak ubahnya sebagai batasan konstitusional pembentuk undang-undang agar mematuhi aspek procedural dalam pembentukan suatu undang-undang.

Lebih lanjut nantinya setelah diatur dalam UUD NRI tahun 1945 terkait asasasas formil pembentukan undang-undang berimplikasi bahwa jelasnya batu uji

\footnotetext{
${ }^{70}$ Keterangan ahli Susi Dwi Harijanti dalam Judicial Review di MK Undang-Undang Nomor 19 tahun 2019.[63].
} 
yang akan digunakan Mahkamah Konstitusi dalam melakukan pengujian formil. Hal ini dikarenakan fungsi lain dari asas pembentukan undang-undang menurut Philipus M. Hadjon sebagai dasar pengujian atau batu uji dalam pembentukan aturan hukum atau uji formal maupun sebagai dasar pengujian terhadap aturan hukum yang berlaku atau uji materil. ${ }^{71}$ Mendasarkan pada permasalahan yang ada, asas yang diusulkan Penulis untuk dimasukkan ke dalam suatu pembentukan undang-undang adalah asas keterbukaan dan kedayagunaan. Asas keterbukaan berarti bahwa dalam pembentukan undang-undang mulai dari tahap perencanaan, penyusunan, pembahasan, pengesahan, dan pengundangan bersifat transparan dan terbuka dimana seluruh lapisan masyarakat mempunyai kesempatan seluasluasnya untuk terlibat dan memberi masukan terhadap proses tersebut. ${ }^{72}$ Terkait asas kedayagunaan pada prinsipnya menjamin bahwa setiap pembentukan undangundang benar-benar dibutuhkan dan bermanfaat dalam kehidupan berbangsa dan bernegara. ${ }^{73}$ Dengan adanya dua asas ini memberikan suatu konstruksi bahwa pembentukan undang-undang benar-benar partisipatif dan demokratis.

\section{Kesimpulan}

Cita awal perubahan UUD NRI tahun 1945 adalah untuk menghilangkan kekuasaan yang teramat besar Presiden dalam berbagai aspek termasuk proses legislasi. Hal ini sejalan dengan kesapakatan dasar penegasan terhadap presidensiil yang salah satu karakteristiknya adalah pemisahan kekuasaan. Namun hasil perubahan UUD NRI tahun 1945 kewenangan Presiden dalam proses legislasi masih sangatlah besar yang berimplikasi corak yang dibangun lebih condong pada sistem pemerintahan parlementer. Disaat yang bersamaan, kewenangan DPD sebagai kamar kedua yang tak ubahnya sebagai perwakilan territorial yang dibentuk sebagai

\footnotetext{
${ }^{71}$ Philipus M Hadjon, 'Analisis Terhadap UU No. 10 Tahun 2004 Tentang Pembentukan Peraturan Perundang-Undangan', Seminar Hukum Nasional Universitas Airlangga 'Implementasi UU No. 10 Tahun 2004 dalam Legislasi Daerah berdasarakan UU No. 32 Tahun 2004' (Bagian HTN Universitas Airlangga 2005).[3].

72 Putro Astomo, Ilmu Perundang-Undangan, Op.Cit.[98].

73 ibid.[97].
} 
penyalur aspirasi daerah sekaligus melakukan internal checks and balances dalam lembaga legislatif dinilai masih sangat lemah. Oleh sebab itu, untuk mewujudkan suatu lembaga legislative yang benar-benar representatif perlu untuk melakukan penguatan terhadap DPD yang salah satunya mengenai kewenangannya dalam hal legislasi. Dalam hal ini konsep yang diusulkan adalah kewenangan DPD dan DPR benar-benar setara mulai dari perencanaan, pembahasan, hingga persetujuan.

Begitupula sebagai upaya untuk memurnikan sistem presidensiil, kewenangan Presiden untuk terlibat dalam pembahasan dan persetujuan suatu undang-undang juga perlu dihilangkan. Namun, dalan hal ini Presiden tetap berhak untuk mengajukan suatu rancangan undang-undang, Lebih lanjut dalam mekanisme baru ini, Presiden akan diberikan hak veto suatu RUU yang telah disetujui masing-masing oleh DPR dan DPD. Begitupula setelahnya, DPR dan DPD dapat membatalkan veto tersebut dengan proporsi tertentu sehingga suatu rancangan undang-undang akan tetap sah menjadi undang-undang. Dengan mekanisme ini corak yang dibangun benar-benar sesuai dengan sistem presidensiil dan optimalisasi skema checks and balances serta tetap menjamin aspirasi masyarakat tercermin dalam pembentukan undang-undang.

Selain itu permasalahan lain dalam pembentukan undang-undang adalah tidak taat pada asas-asas pembentukan undang-undang. Keadaan ini terlihat dari banyaknya produk undang-undang yang menerabas aspek prosedural tertentu seperti mengenai keterbukaan dan kedayagunaan. Oleh sebab itu, untuk menjawab permasalahan tersebut perlu untuk lebih tegas mengatur mengenai Batasan konstitusional tertentu mengenai aspek formil pembentukan undang-undang sebagai salah satu materi muatan dalam UUD NRI tahun 1945. Selain untuk mewujudkan ketaatan kepada pembentuk undang-undang sesuai mekanisme di atas, asas ini juga dapat dijadikan batu uji apabila diajukan uji formil kepada Mahkamah Konstitusi. Dengan demikian sistem baru yang diusulkan Penulis diharapkan mampu menjawab permasalahan-permasalahan buruknya kualitas legislasi di Indonesia untuk mewujudkan pembentukan undang-undang yang lebih demokratis, representatif, dan transparan. 


\section{Daftar Bacaan}

\section{Buku}

Anom Husodo Djatmiko, Dewan Perwakilan Daerah dan Masa Depan Bikameralisme Indonesia, dalam Gagasan Amandemen UUD 1945 Suatu Rekomendasi (Komisi Hukum Nasional RI 2008).

Arend Lijphart, Paterns of Democracy: Government Forms and Performance in Thirty-Six Countries (Yale Univesity Press 1999).

Arnold J. Zurcher, Constitution and Constitutional Trends Since World War II (New York University Press 1956).

Badan Pembinaan Hukum Nasional. Laporan Akhir Pengkajian Hubungan Lembaga Negara Pasca Amandemen UUD 1945 (BPHN RI 2005).

Bagir Manan, Teori dan Politik Konstitusi (UII Press 1999).

Bayu Dwi Anggono, Perkembangan Pembentukan Undang-Undang di Indonesia (Konstitusi Press 2014).

Denny Indrayana, Teori Lembaga Kepresidenan (Departemen HTN FH UGM, n.d).।

Fakultas Hukum UGM. Kertas Kebijakan: Catatan Kritis dan Rekomendasi Terhadap RUU Cipta Kerja (Fakultas Hukum UGM 2020).

Jimly Asshiddiqie, Format Kelembagaan Negara dan Pergeseran Kekuasaan dalam UUD 1945 (FH UII Press 2004).

Jimly Asshiddiqie, Format Kelembagaan Negara dan Pergeseran Kekuasaan dalam UUD 1945 (FH UII Press 2004).

Jimly Asshiddiqie, Konstitusi dan Konstitusionalisme di Indonesia (Sinar Grafika 2011).

Jimly Asshiddiqie, Perihal Undang-Undang di Indonesia (Sekretariat Jenderal dan Kepaniteraan MK RI 2006)

Jimly Asshiddiqie, Perkembangan dan Konsolidasi Lembaga Negara Pasca Reformasi (Sinar Grafika 2012).

John H. Garvey dan Alexander Aleinikoff, Modern Constitutional Theory: A Reader 5th Edition (West Group Publishing 1999).

Juanz J. Linz dan Arturo Valenzuela, The Failure of Presidential Democracy (Johns 
Hopkins University Press 2001).

Karl Loewenstein, Reflections on the Value of Constitutions in Our Revolutionary Age (New York University Pers 1995).

KC. Wheare, Modern Constitution (Oxford University Press 1975).

Majelis Permusyawaratan Rakyat, Panduan Pemasyarakatan Undang-Undang Dasar 1945 Negara Republik Indonesia tahun 1945 dan Ketetapan Majelis Permusyawaratan Rakyat Republik Indonesia (Sekretariat Jenderal MPR RI 2014).

Maria Farida Indrati, Ilmu Perundang-Undangan 1: Jenis, Fungsi, dan Materi Muatan (Kanisius 2002).

Michael Hishikusthija, Perbandingan Bikameral dan Proses Perubahan Konstitusional (Forum Rektor Indonesia 2001).

Miriam Budiardjo, Dasar-Dasar Ilmu Politik (Gramedia Pustaka 1991).

Mukti Fajar dan Yulianto Ahmad, Dualisme Peneltiaian Hukum Normatif dan Empiris (Pustaka Pelajar 2010).

Ni'matul Huda, UUD 1945 dan Gagasan Amandemen Ulang (Raja Grafindo Persada 2008).

Pan Mohamad Faiz, Amandemen Konstitusi : Komparasi Negara Kesatuan dan Negara Federal (Raja Grafindo Persada 2017).

Pan Mohamad Faiz, Amandemen Konstitusi : Komparasi Negara Kesatuan dan Negara Federal (Raja Grafindo Persada 2019).

Robert L. Maddex, The Illustrated Dictionary of Constitutional Concept (Congressional Quarterly Inc 1996).

Saldi Isra dan Zainal Arifin Mochtar, Konsep Ideal Bikameral yang Sesuai dengan Keadaan dan Pemerintahan Demokratis di Indonesia (Raja Grafindo Persada 2007).

Saldi Isra, Pergeseran Fungsi Legislasi (Raja Grafindo Persada 2018).

Sekretariat DPD RI. Bikameral Bukan Federal (DPD-RI 2005).

Soerjono Soekanto, Pengantar Penelitian Hukum (UI Press 2010). 


\section{Jurnal}

Miki Pirmansyah, 'Eksistensi DPD Dalam Sistem Bikameral di Indonesia' (2014) 01 Jurnal Cita Hukum.

Ryan Mutiara Wasthi, 'Fungsi Representasi Dewan Perwakilan Daerah Republik Indonesia' (2017) 47 Jurnal Hukum \& Pembangunan.

Sally Falk Moore,'Law and Social Change: The Semi-Autonomous Social Field As An Approriate Subject of Study' (1973) 7 no 4 Law and Society Review.

Wantu Satrio, 'Memperkuat Fungsi Legislasi DPRD Sebagai Format Policy Dalam Euphoria Otonomi' (2012) 5 Jurnal Legalitas.

Widayati, 'Sistem Parlemen berdasarkan Konstitusi Indonesia' (2015) 44 no. 4 $\mathrm{MMH}$

\section{Makalah}

Bivitri Susanti, 'Penguatan Kewenangan DPD dan Pasal-Pasal Lain yang Terkait di Bidang Legislasi, Anggaran, dan Pengawasan' In Pertemuan Ahli Hukum Tata Negara, Universitas 1945 Makassar (Universitas 1945 Makassar 2007).

Dhalan Thaib, 'Menuju Parlemen Bikameral' In Sidang Senat Terbuka UII Yogyakarta. (FH UII Press 2003).

\section{Perundang-undangan}

Undang-Undang Dasar Negara Republik Indonesia Tahun 1945.

Undang-Undang Nomor 12 Tahun 2011 tentang Pembentukan Undang-Undang.

Undang-Undang Nomor 17 Tahun 2014 tentang Majelis Permusyawaratan Rakyat, Dewan Perwakilan. Rakyat, Dewan Perwakilan Daerah, dan Dewan Perwakilan Rakyat Daerah

\section{Laman}

Robert Dahl, "Rousseau and Democracy."(Encyclopaedia Britannica 2020). https:// www.britannica.com/topic/democracy/Rousseau/. accessed 1 November 2020 .

Liputan6.com. “DPD Targetkan RUUDaerah Kepulauan Disahkan 2020." (Liputan 6 2019) <https://www.liputan6.com/news/read/4140154/dpd-targetkan-ruudaerah-kepulauan-disahkan-pada-2020> accessed 1 November 2020. 
Sania Mashabi, "Revisi UU KPK Dinilai Cacat Formil." (Liputan 6 2019) https:// www.liputan6.com/news/read/4057630/revisi-uu-kpk-dinilai-cacat-formil accessed 19 October 2020.

DPR RI, "Program Legislasi Nasional Prioritas RI - Prolegnas 2015-2019 dan Prolegnas 2020-2024." (DPR R, 2019) < http://www.dpr.go.id/uu/prolegnas> accessed 20 October 2020 .

Richo Andi Wibowo, “Masalah Turunan Pasca 'Sulap' UU KPK." (JawaPos 2019) <https://www.jawapos.com/opini/18/09/2019/masalah-turunanpasca-sulap-uu-kpk/> accessed 19 October 2020.

BBC News Indonesia "Isi Omnibus Law: Dokumen Final UU Cipta Kerja Belum Diakses Publik, Dikhawatirkan Pasal Selundupan.” (BBC Indonesia 2020). <https://www.bbc.com/indonesia/indonesia-54501112.> accessed 20 October 2020.

\section{Lain-Lain}

Mahkamah Konstitusi. "Risalah Sidang Pengujian Formil dan Materiil UndangUndang Nomor 19 tahun 2019 tentang Perubahan Kedua atas UndangUndang Nomor 30 tahun 2002 atas Undang-Undang Nomor 30 tahun 2002 tentang Komisi Pemberantasan Tindak Pidana Korupsi.” 2019. 